\title{
Integrasi \\ Tri Pusat Pendidikan dalam Pendidikan Agama Islam
}

\author{
Samsudin \\ Prodi Manajemen Pendidikan Islam \\ STIT Islamiyah Karya Pembangunan Paron, Ngawi, Jawa Timur \\ Email: Samsudinsamsudin231@gmail.com
}

\begin{abstract}
In globalization epoch met by many big influence to society. Influence of good terebut not all but there is also negative influence. Education of Islam as one of the stock to realize real moslem. At its execution of education of application Islam have to pass three education center. Three the education center cover family, society and school. In conducting this research, researcher use research type qualitative. So that the following research mengasilkan: (1) Three education center is three education center covering family, society and school. Third of the environment have responsibility and duty in educating nation child. Family, society and school as underwriter of answer education which must always work along harmoniously. From third the education environment will fall to pieces do not walk one way otherwise keep together. (2) Third education environment as place inculcate Islam teaching values having a purpose to form child become person which either through spirit and also bodily. Family as cultivation first time about Islam teaching, go to school as medium to develop and society as medium for the application of it. (3) Education of Islam represent one of the good stock of life of and also world of eternity. So that execution of process education of Islam must be done pass three education center. Role of family, compact society and school will have strong influence in creating human resource which is genius, high with quality and have august personality
\end{abstract}

Keywords: Family, School, Society and PAI

\section{Pendahuluan}

Sebagai fenomena universal dan komparatif, modernisasi menurut Inkeles (1966) dicirikan oleh sejumlah kecenderungan, yaitu : (1) menyetujui gagasan baru dan berani menguji coba metode dan teknik baru, (2) kesiapan menyatakan pendapat, (3) berorientasi pada masa kini dan mendatang daari pada masa silam, (4) menghargai ketepatan waktu, (5) melakukan perencanaan, organisasi, dan efisiensi, (6) melihat dunia ini sebagai hal yang dapat di kalkulasi, (7) percaya akan sains dan teknologi, (8) melihat pentingnya pemerataan keadilan. ${ }^{1}$ Modernisasi yang mantap dicirikan oleh munculnya kedelapan kriteria tersebut secara kolektif dalam sebuah pranata sosial. Kedelapan pasal tersebut menjadi sikap sekaligus keyakinan semua unsur masyarakat, baik personal maupun institusional, termasuk di dalamnya dunia pendidikan. Dengan demikian,

${ }^{1}$ Inkeles. "The Modernization of Man," dalam Weimer (ed). Modernization: The Dynamics of Growth. (Voice of Amerika Forum Lectures, 1966), 151 
sebagai sebuah institusi, pendidikan pada prinsipnya memikul amanah "etika masa depan".

Etika masa depan timbul dari dan dibentuk oleh kesadaran bahwa semua manusia, sebagai individu maupun kolektif akan menjalani sisa hidupnya di masa depan bersama dengan sesama makhluk hidup lainnya yang ada di muka bumi. Hal ini berarti bahwa etika masa depan menuntut manusia untuk tidak mengelakkan tanggung jawab atas konsekuensi dari setiap perbuatan yang dilakukannya di masa sekarang.

Etika masa depan sebagaimana dimaksud di atas tidak sama dengan etika di masa depan; etika masa depan adalah etika masa kini untuk masa depan. Sebab di masa depan, tanpa adanya etika masa depan sekarang ini, semuanya sudah menjadi terlambat. Oleh karena itu, dalam etika masa depan terkandung keharusan agar manusia berani menjawab tantangan terhadap kemampuan yang khas yang manusiawi untuk mengantisipasi, merumuskan nilai-nilai, dan menetapkan prioritas-prioritas dalam suasana yang tidak pasti agar generasi-generasi mendatang tidak menjadi mangsa dari proses yang menjadi semakin tidak terkendali di zaman mereka di kemudian hari. ${ }^{2}$

Berbicara mengenai konteks etika masa depan, maka sudah seharusnya visi pendidikan lahir dari kesadaran bahwa manusia sebaiknya jangan menanti apapun dari masa depan, karena sesungguhnya masa depan itulah mengharap-harapkan dari kita, kita sendirilah yang seharusnya menyiapkannya.

Suyudi (2005) mengungkapkan bahwa pendidikan merupakan seluruh aktivitas atau upaya sadar yang dilakukan oleh pendidik kepada peserta didik terhadap semua aspek perkembangan kepribadian baik jasmani maupun rohani, secara formal, informal maupun non formal yang berjalan terus menerus untuk mencapai kebahagiaan dan nilai yang tinggi, baik nilai insaniyah maupun ilahiyah. ${ }^{3}$ Menurut Zuhairini, sebagaimana yang dikutip oleh Muhaimin menjelaskan bahwa dalam Islam pada mulanya pendidikan disebut dangan kata " $t a$ 'lim" dan " $t a$ 'dib" mengacu pada pengertian yang lebih tinggi, dan mencakup unsur-unsur pemgetahuan ('ilm), pengajaran ( $\left.t a^{\prime} l i m\right)$ dan bimbingan yang baik (tarbiyah). ${ }^{4}$

Berdasar uraian diatas maka dapat disimpulkan bahwa pendidikan adalah suatu aktivitas untuk mengembangkan seluruh aspek kepribadian manusia untuk membina kepribadian sesuai dengan nilai-nilai di dalam masyarakat dan kebudayaan yang berjalan

\footnotetext{
2 Joesoef, Daoed, "Pembaharuan Pendidikan dan Pikiran", dalam Sularto (ed). Masyarakat Warga dan Pergulatan Demokrasi: Antara Cita dan Fakta. (Jakarta: Kompas, 2001), 197

${ }^{3}$ Suyudi, Pendidikan dalam Perspektif Al-Qur'an. (Yogyakarta: Penerbit Mikeraj, 2005), 54

${ }^{4}$ Muhaimin, Paradigma Pendidikan Islam. Bandung: PT. Remaja Rosdakarya, 2002), 36.
} 
seumur hidup. Pendidikan tidak hanya berlangsung di dalam kelas, tetapi berlangsung pula di luar kelas. Freire mengatakan bahwa pendidikan harus mampu mengubah paradigma pemikiran masa lalu sebagai sekat yang menghimpit, yang membuat manusia "terbuai" dalam "hari ini" yang panjang, monoton dan membosankan, sedang masa lalu dan masa akan datang belum disadari.

Pendidikan bukan melanggengkan status quo kebudayaan bisu dimasyarakat, akan tetapi pendidikan seharusnya memberikan kesadaran dan pemberdayaan (selfempowering) bagi manusia terhadap penindasan. ${ }^{5}$ Salah satu kritik Freire mengatakan bahwa adalah pendidikan yang pada awalnya merupakan upaya membebaskan kaum tertindas pada kenyataannya hanya mencetak peserta didik untuk menjadi penindas baru. Bagi Freire pembebasan kaum tertindas tidak dimaksudkan supaya ia bangkit menjadi penindas baru, tetapi supaya sekaligus membebaskan para penindas dari kepenindasannya.

Pendidikan sebagai upaya untuk memberikan solusi perkembangan dan perubahan kemanusiaan secara dinamik dan gradual berkaitan erat dengan sosok pendidik. Pendidik sebagai penolong, berusaha memberikan bantuan kepada peserta didik untuk mengembangkan dirinya secara utuh sebagai manusia berdasarkan kasih.

Zaman modern seperti saat ini, mengatasi problematika bangsa pendidikan merupakan upaya yang menjadi alternatif dan instrumen untuk membentuk generasi ideal masa bangsa. Pendidikan merupakan aspek sosial budaya yang berperan sangat setrategis. Dalam proses memanusiakan siswa dari yang tidak tahu menjadi tahu merupakan suatu usaha yang dilaksanakan secara sadar, sistematis, terarah dan terpadu. Melalui pendidikan generasi bangsa bisa tumbuh secara efektif dan efisien. ${ }^{6}$

Pendidikan sebagai lembaga sosial yang berkontribusi untuk manusia dalam mempertahankan budaya dan kelangsungan hidup. Dalam membentuk kepribadian, ketrampilan, menanamkan nilai-nilai, pembentukan kesadaran bangsa, pengembangan pengetahuan, teknologi dan segala unsur peradaban manusia sangat memerlukan pendidikan. Begitu pentingnya makna pendidikan bagi manusia. ${ }^{7}$ Terutama pendidikan Islam yang berpengaruh besar dalam kehidupan bermasyarakat. Dengan perantara

${ }^{5}$ Untuk pembacaan lebih lanjut, lihat Chaer, "Self-Efficacy dan Pendidikan." AL MURABBI: Jurnal Studi Kependidikan dan Keislaman, Volume 3, Nomor 1, Juli 2016 ISSN 2406-775X, http://ejournal.kopertais4.or.id/mataraman/index.php/murabbi/article/view/1722; Chaer, "Peran Madrasah dalam Menghadapi Era Globalisasi dan Budaya."

${ }^{6}$ M. Suyudi, Rancang Bangun Pendidikan Islam, (Yogyakarta: Belukar, 2014), 31

7 Hanun Asrohah dan Anas Alamsyah, Buku Ajar Pengembangan Kurikulum, Cetakan ke-4, (Surabaya: Kopertais IV Press, 2012), 21 
pendidikan Islam masyarakat mampu memfilter berbagai dampak dari kemajuan tehnologi yang semakin canggih.

Sebagai salah satu agama, Islam mempunyai ajaran yang sempurna dan komperhensif dari pada agama lainnya. Agama Islam merupakan pedoman manusia sampai akhir zaman, karena Islam sebagai agama yang sempurna dan menjadi panutan umat muslim dimanapun berada. ${ }^{8}$ Ajaran Islam dipahami dan diaplikasikan melalui proses pendidikan, tanpa pendidikan tidak akan bisa mengetahui ajarannya. Pendidikan Islam lebih fokus pada perbaikan sikap mental yang terwujud dalam segi amal perbuatan. Disisi lain pendidikan Islam tidak hanya bersifat teoritis saja, tetapi juga praktis. Ajaran Islam tidak terpisahkan antara kepercayaan dan perbuatan. ${ }^{9}$

Pendidikan sebagai proses penyempurnaan individu diupayakan berkelanjutan dan berlangsung ke generasi selanjutnya. ${ }^{10}$ Dalam pelaksanan pendidikan Islam, lingkungan menjadi salah satu unsur untuk mentukan corak pendidikan Islam. Dalam proses perkembangan peserta didik lingkungan mempunyai dampak yang baik dan buruk. Dampak yang baik mampu memberikan dorongan serta rangsangan untuk melakukan suatu perbuatan yang positif. Namun, dampak yang buruk tidak mampu untuk memberikan motivasi terhadap anak didik, justru menjadi kendala untuk perkembangan anak didik. ${ }^{11}$

Pada kenyataannya pendidikan mempunyai lingkungan sebagai agen sosialisasi. Seorang anak bergaul dalam kehidupan sehari-hari dan melakukan proses pendidikan. ${ }^{12}$ Lingkungan tersebut meliputi keluarga, sekolah dan masyarakat. Ketiga lingkungan pendidikan tersebut bisa dikatakan dengan tri pusat pendidikan. Karena pada prosesnya pendidikan tidak hanya dilakukan di bangku sekolah saja. Dengan ketiga lingkungan tersebut sama-sama mempunyi tanggungjawab besar dalam mendidik anak menjadi generasi penerus bangsa yang handal.

Sebagai salah satu dari lingkungan pendidikan Islam, keluarga tempat yang pertama dalam mengajarkan anak tentang akhlakul karimah seperti yang tercantumkan dalam Islam. Ajaran akhlak dalam Islam meliputi sifat jujur, ikhlas, sabar, sopan santun dan berbuat kebaikan. Sejak anak usia dini keluarga sudah menanamkan nilai dan norma

${ }^{8}$ Suyudi, Filsafat Pendidikan Islam dalam Kajian Filososfis dan Pemikiran Pendidikan Islam, (Yogyakarta: Belukar, 2014), 5

${ }_{9}^{9}$ Nur Uhbiyati, Imu Pendidikan Islam, Cetakan ke-2, (Bandung: CV. Pustaka Setia, 1998), 11

10 Doni Koesoema A, Pendidikan Karakter: Strategi Mendidik Anak di Zaman Global, Jakarta: Grasindo, 2007), 312

11 Zuhairini, et.al., Filsafat Pendidikan Islam, Cetakan ke-2, (Jakarta: Bumi Aksara, 1995), 173

12 Mangun Budiyanto, Ilmu Pendidikan Islam, (Yogyakarta: Griya Santri, 2010), 169 
yang baik sesuai dengan syariat Islam. ${ }^{13}$ Pada masa kejayaan Islam yang menjadi faktor pendukungnya adalah akhlak yang mulia. ${ }^{14}$ Sepanjang sejarah akhlak menjadi bagian yang utama dalam kehidupan.

Pada lingkungan keluarga tugas pendidikan tidak semuanya mampu dilaksanakan terutama dalam hal iptek, sehingga orang tua menyerahkan sebagian kepada sekolah. Anak didik diberi ilmu dan teladan yang baik oleh seorang guru melalui kegiatan belajar mengajar di sekolah. Dengan berpedoman pada agama Islam dan berkepribadian muslim sejati, mereka mampu menjadi masa depan bangsa yang hebat dan tangguh. Untuk proses selanjutnya pendidikan dilaksanakan di sekolah.

Lingkungan sekolah mempunyai peran yang tidak bisa terlepaskan dengan bantuan dari lingkungan pendidikan yang lain. Untuk itu, lingkungan masyarakat ikut andil dalam proses pendidikan. Sebagai lembaga sosial masyarakat mempunyai beraneka ragam kelompok sosial yang bisa mendukung suksesnya pendidikan. Secara informal nilai-nilai ajaran agama Islam dilaksanakan dalam lingkungan keluarga yaitu melalui pengamalan kehidupan sehari-hari. Secara formal nilai-nilai ajaran agama Islam dilaksanakan di lingkungan secara sistematis. Sementara untuk lingkungan masyarakat dilakukan secara non formal.

Berdasarkan pengamatan penulis zaman sekarang diprosentasekan bahwa 50\% proses pendidikan dikeluarga, karena keluarga sebagai peletak dasar pendidikan akhlak. Keluarga yang pertama kali mengenalkan syiar Islam mengenalkan ajaran Islam. 25\% proses pendidikan berlangsung di sekolah. Di sekolah sebagai wahana mengembangkan pola kelakuan untuk mencapai tujuan. Sedangkan yang 25\% dilaksanakan di masyarakat. Karena masyarakat pengaktualisasian diri untuk mewujudkan kemadirian. Pendidikan agama Islam sebagai alat untuk membentengi diri dari goncangan kehidupan. Dengan bekal pengetahuan agama Islam yang kuat, tidak akan mudah terpengaruh oleh rayuan yang akan menjajah orang Islam. Saat ini bangsa banyak dirundung berbagai kasus diantaranya umat Islam berselisih dengan sesama muslim. Sehingga dengan fenomena tersebut, nilai-nilai agama Islam harus benar-benar diterapkan sedini mungkin bahkan sejak usia kandungan.

Lingkungan yang asri dibutuhkan untuk mencapai tujuan pendidikan agama Islam. Karena lingkungan memberikan dampak yang positif dan negatif dalam

\footnotetext{
${ }^{13}$ Hasan Langgulung, Manusia dan Pendidikan: Suatu Analisa Psikologis dan Pendidikan, Cetakan ke3, (Jakarta: Al-Husna Zikra, 1995), 374

14 Imam Pamungkas, Akblak. Muslim Modern: Membangun Generasi Muda, (Bandung: Marja, 2012), 12
} 
pertumbuhan kepribadian anak. Tidak semua orang tua menyadari begitu pentingnya menanamkan pendidikan agama pada keluarga. Banyak orang yang terlalu percaya dengan pendidikan di sekolah, padahal proses pendidikan disekolah hanya berlangsung beberapa jam saja. Orang tua yang terlalu sibuk dengan urusan masing-masing. Sehingga, mereka menganggap bahwa pendidikan yang paling utama di sekolah saja. Hal tersebut jika dibiarkan akan memicu munculnya kenakalan remaja, karena anak tidak dibekali pendidikan agama sejak usia dini.

Melihat fenomena tersebut, pendidikan agama Islam mempunyai peran yang urgen dalam dinamikan sosial, yakni menumbuhkembangkan mutu sumber daya manusia agar umat Islam mampu menjadi insan yang terdepan dalam menghadapi modernisasi. Pendidikan Islam melahirkan manusia yang mempunyai pribadi mulia lahir batin. Dalam membentuk pribadi tersebut sangat dibutuhkan motivasi, ikhtiar dan do'a yang sangat kuat. Selain itu, dalam mewujudkan pendidikan sangat membutuhkan berbagai faktor. Faktor tersebut salah satunya adalah lingkungan yang meliputi keluarga, sekolah dan masyarakat. Melalui lingkungan pendidikan dapat mempengaruhi perkembangan anak baik secara fisiologis, psikologis maupun sosio-kultural.

\section{Pembahasan}

\section{Tripusat Pendidikan}

\section{a. Keluarga}

Secara etimologi keluarga adalah kamula atau warga. Kawula berarti “abdi” atau hamba sedangkan warga artinya anggota. Sebagai abdi didalam keluarga wajiblah menyerahkan segala kepentingannya kepada keluarganya. Sebaliknya sebagai warga atau anggota ia berhak sepenuhnya ikut mengurus segala kepentingan dalam keluarganya. ${ }^{15}$

15 Abu Ahmadi dan Nur Uhbiyati, Ilmu Pendidikan, Cetakan ke-3, (Jakarta:Rineka Cipta, 1991), 176. Istilah keluarga menurut Kamus Besar Bahasa Indonesia memiliki beberapa arti. Pertama, ibu dan bapak beserta anak-anaknya; seisi rumah. Kedua, orang seisi rumah yang menjadi tanggungan; batih. Ketiga, jika digandeng dengan kata "kaum", berarti sanak saudara; kaum kerabat. Keempat, satuan kekerabatan yang sangat mendasar di dalam masyarakat. Dalam ranah Sosiologi, keluarga (family) difahami sebagai kesatuan kemasyarakatan (sosial) berdasarkan hubungan perkawinan atau pertalian darah. Keluarga dalam pengertian seperti ini terbagi menjadi dua, yaitu keluarga batih (inti) dan keluarga parsial. Keluarga batih (nuclear family, basic family, primary family, elementary family, conjugal family) merupakan kerabat terkecil yang terdiri atas ayah, ibu, dan anak-anak mereka. Sedangkan keluarga parsial adalah keluarga yang hanya terdiri atas suami dan istri tanpa anak. Sebagai perbandingan lihat, Herien Puspitawati, Konsep dan Teori Keluarga, (Bogor : PT IPB Press, 2013), 2; Tim Penyusun Kamus Pusat Bahasa Departemen Pendidikan Nasional, Kamus Besar Bahasa Indonesia, Edisi III (Jakarta: Balai Pustaka, 2005), 536; Hassan Shadily dkk., Ensiklopedi Indonesia (Jakarta: Ichtiar Baru-Van Hoeve, t.t.), 1729; William J. Goode, Sosiologi Keluarga 
Pendidikan dilaksanakan melalui tiga jalur yaitu, pendidikan jalur sekolah (formal), non formal dan informal. Pendidikan jalur non formal adalah pendidikan di luar sekolah atau pendidikan masyarakat, dalam pendidikan masyarakat ini yang dipelajari harus sesuai dengan kebutuhan perkembangan masyarakat itu sendiri. Sedangkan pendidikan informal adalah pendidikan keluarga bersifat kodrati dalam hal ini orang tualah yang sangat berperan dalam melaksanakan pendidikan anaknya. ${ }^{16}$ Keluarga $^{17}$ menjadi salah satu lingkungan dalam dunia pendidikan, di mana orang tua sebagai pendidik ${ }^{18}$ yang bertanggung jawab memelihara, merawat, melindungi dan mendidik anak agar tumbuh dan berkembang dengan baik.

Pendidikan agama dalam lingkungan keluarga merupakan agen sosialisasi pendidikan pertama kali. Melalui keluarga manusia lahir dan berkembang menjadi pribadi yang mandiri. Aspek pendidikan didalam keluarga akan mempengaruhi tumbuh kembang watak, budi pekerti dan kepribadian manusia. Pendidikan yang diterima dalam keluarga akan digunakan sebagai dasar untuk mengikuti pendidikan yang selanjutnya. ${ }^{19}$

Keluarga sebagai agen sosialisasi primer utama, seorang bayi menemukan ibunya. Pelukan, belaian dan kasih secara fisik ini merupakan pelajaran pertama tentang aspek afeksi-emosional. Pelajaran berikutnya seperti nilai, norma, sikap dan

(Jakarta: PT Bumi Aksara: 2002), 370; Fuaduddin, Pengasuhan anak dalam keluarga Islam (Jakarta: Lembaga kajian Agama dan Jender, 2009), 7.

16 Suwarno, Pengantar Umum Pendidikan, (Surabaya: Aksara Baru, 1995), hal. 66, lihat juga Hasbullah, Dasar-Dasar Ilmu Pendidikan, (Jakarta : Raja Grafindo Persada, 2006), 38.

${ }^{17}$ Istilah keluarga menurut Kamus Besar Bahasa Indonesia memiliki beberapa arti. Pertama, ibu dan bapak beserta anak-anaknya; seisi rumah. Kedua, orang seisi rumah yang menjadi tanggungan; batih. Ketiga, jika digandeng dengan kata "kaum", berarti sanak saudara; kaum kerabat. Keempat, satuan kekerabatan yang sangat mendasar di dalam masyarakat. Dalam ranah Sosiologi, keluarga (family) difahami sebagai kesatuan kemasyarakatan (sosial) berdasarkan hubungan perkawinan atau pertalian darah. Keluarga dalam pengertian seperti ini terbagi menjadi dua, yaitu keluarga batih (inti) dan keluarga parsial. Keluarga batih (nuclear family, basic family, primary family, elementary family, conjugal family) merupakan kerabat terkecil yang terdiri atas ayah, ibu, dan anak-anak mereka. Sedangkan keluarga parsial adalah keluarga yang hanya terdiri atas suami dan istri tanpa anak. Sebagai perbandingan lihat, Herien Puspitawati, Konsep dan Teori Keluarga, (Bogor : PT IPB Press, 2013), 2; Tim Penyusun Kamus Pusat Bahasa Departemen Pendidikan Nasional, Kamus Besar Bahasa Indonesia, Edisi III (Jakarta: Balai Pustaka, 2005), 536; Hassan Shadily dkk., Ensiklopedi Indonesia (Jakarta: Ichtiar Baru-Van Hoeve, t.t.), 1729; William J. Goode, Sosiologi Keluarga (Jakarta: PT Bumi Aksara: 2002), 370; Fuaduddin, Pengasuban anak dalam keluarga Islam (Jakarta: Lembaga kajian Agama dan Jender, 2009), 7.

${ }^{18}$ Fuad Ihsan, Dasar-Dasar Kependidikan, cet. ke-7 (Jakarta : Rineka Cipta, 2011), 576. Keluarga merupakan sekelompok kecil yang menjadi penunjang dan pembangkit dalam mewujudkan suatu bangsa dan negara. Selain itu, keluarga dapat dikatakan roh masyarakat dan tulang punggungnya. Wujud dan kondisi dalam kehidupan keluarga dalam masyarakat merupakan kesejahteraan yang dirasakan oleh sebuah bangsa. Namun sebaliknya, keterbelakangan bangsa merupakan wujud dari keluarga yang didalamnya, lihar Muhammad 'Abd al-'Aliy, the Family Structure in Islam (Maryland: International Gfaric Printing Service, t.th), 9. M. Quraish Shihab, Membumikan al-Qur'an, Cetakan XV, (Bandung: Mizan, 1997), 255.

${ }^{19}$ Fuad Ihsan, Dasar-Dasar Kependidikan, (Jakarta: PT Rineka Cipta, 1997), 57 
harapan diterima dari keluarga seiring dengan berjalannya waktu yang terkait dengan pertambahan usia. ${ }^{20}$

Sebagai orang tua yang baik mempunyai tanggung jawab yang penuh dalam mendidik dan menumbuhkembangkan anak sampai usia dewasa. Dalam mewujudkan pribadi anak yang baik, orang tua harus selalu memberikan teladan yang baik terhadap anaknya. Karena setiap gerak dan tingkah laku orang tua akan ditiru oleh anak. Ketika orang tua memberikan pengajaran terhadap anak harus dengan kasih sayang tidak bersikap kasar. Melalui sikap kasih sayang anak lebih taat pada orang tua dan tidak merasa tertekan. ${ }^{21}$

Pendidikan keluarga sebagai pendidikan alamiah yang melekat pada setiap rumah tangga. Institusi keluarga merupakan lingkungan pertama yang dijumpai anak dan yang mula-mula memberikan pengaruh yang mendalam serta memegang peranan utama dalam proses perkembangan anak. Menurut Hurlock, istilah perkembangan berarti serangkaian perubahan progresif yang terjadi sebagai akibat dari proses kematangan dan pengalaman. ${ }^{22}$

Menurut Shihab (2007) perlindungan anak dalam agama, menuntut adanya pendidikan agama bagi anak di rumah dan di lembaga pendidikan di mana dia belajar, sesuai dengan agama yang dianut orangtuanya. Hal ini menjadi satu keharusan untuk menjaga dan melindungi fitrah pada diri manusia. Di sisi lain, tidak jarang orangtua didorong oleh keinginannya yang menggebu menuntut dari anak cara kehidupan beragama yang tidak sesuai dengan pertumbuhan fisik dan perkembangan jiwanya. ${ }^{23}$ 2012), 70

${ }^{20}$ Damsar, Pengantar Sosiologi Pendidikan, Cetakan ke 2, (Jakarta: Kencana Prenada Media Group, 2007), 25

21 Abu Ahmadi dan Nur Uhbiyati, Imu Pendidikan, Cetakan ke 2, Jakarta: PT. Rineka Cipta,

${ }^{22}$ Elisabeth B. Hurlock, Psikologi Perkembangan, Suatu Pendekatan Sepanjang Rentang Kehidupan, edisi kelima, alih bahasa, Istiwidayanti, Soedjarwo, (Jakarta: Erlangga, th), hlm. 2. Mengutip Van den Daele, Hurlock mengatakan bahwa perkembangan berarti perubahan secara kualitatif, ini berarti bahwa perkembangan bukan sekedar penambahan beberapa sentimeter pada tinggi badan seseorang atau peningkatan kemampuan seseorang, melainkan suatu proses integrasi dari banyak struktur dan fungsi yang kompleks. Pada dasarnya ada dua proses perkembangan yang saling bertentangan yang terjadi secara serempak selama kehidupan, yaitu pertumbuhan atau evolusi dan kemunduran atau involusi, lihat selengkapnya dalam Elisabeth B. Hurlock, Psikologi Perkembangan, Suatu Pendekatan Sepanjang Rentang Kebidupan....2. Menurut Andi Mappiare sebagaimana mengutip Elizabeth B.Hurlock bahwa jika dibagi berdasarkan bentuk-bentuk perkembangan dan pola-pola perilaku yang nampak khas bagi usia-usia tertentu, maka rentangan kehidupan terdiri atas sebelas masa, lihat selengkapnya dalam Andi Mappiare, Psikologi Remaja, (Surabaya: Usaha Nasional, 1982), 24 -25. Penjelasan yang lebih rinci dapat dilihat Elisabeth B. Hurlock, Psikologi Perkembangan, Suatu Pendekatan Sepanjang Rentang Kehidupan, 27, 51, 75, 107, 145, 183, 205, dan seterusnya

${ }^{23}$ M. Quraish Shihab, Secercah Cahaya Ilahi, (Bandung: PT Mizan Pustaka, 2007),110 
Upaya pendidikan dalam keluarga perlu dasar yang bersifat transenden, universal dan urgen. Dalam hal ini dasar pendidikan yang harus dilakukan dalam keluarga telah banyak disebutkan dalam Al-Qur'ân, hadis maupun ijmak ulama. Firman Allah dalam al-Qur'ân:

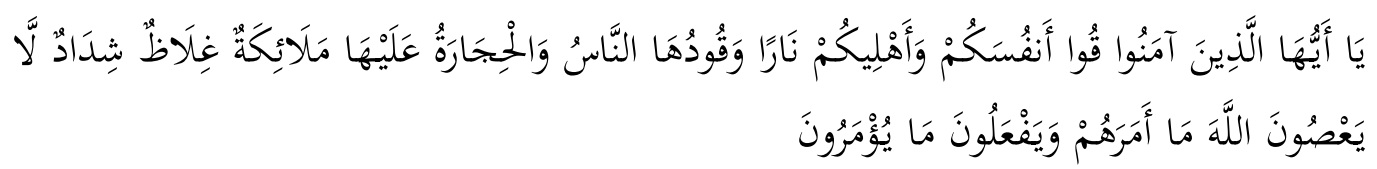

Hai orang orang yang beriman, peliharalah dirimu dan keluargamu dari api neraka yang bahan bakarnya adalah manusia dan batu; penjaganya malaikat-malaikat yang kasar, keras, dan tidak mendurhakai Allah terhadap apa yang diperintahkan-Nya kepada mereka dan selalu mengerjakan apa yang diperintahkan. ( Q.S. At-Tahrim: $6)^{24}$

Pendidikan dalam keluarga dilaksanakan atas dasar cinta dan kasih sayang. Kedua rasa tersebut menjadi kobaran api yang tak kunjung padam pada orang tua untuk anak dan orang tua ikhlas mengorbankan segala sesuatunya demi kepentingan anaknya. Namun, dalam orang tua memberikan bimbingan, hendaklah benar-benar yang bermanfaat untuk pertumbuhan anak menuju kedewasaan, kearah sikap yang mandiri. ${ }^{25}$

Berdasarkan Q.S. At-Tahrim: 6 diatas, dapat diketahui bahwa orang tua mempunyai tangung jawab yang penuh dalam mendidik anak. Sebagai amanat dari Sang Pencipta, anak diamanahkan kepada kedua orang tua untuk dididik dan dimintai pertanggungjawaban nantinya di hari akhir. Pada faktanya seorang anak dalam lingkungan keluarga dituntut untuk belajar dan taat pada orang tua. Sedangkan seorang ayah mempunyai peran yang penting dalam mencari nafkah untuk kebutuhan keluarganya. Sedangkan seorang ibu lebih fokus dalam mengatur dan mengurus rumah tangga serta mendidik anak.

\section{b. Sekolah}

Sekolah merupakan lingkungan pendidikan Islam yang kedua setelah keluarga. Eferett Reimer berpendapat, sebagaimana yang dikutip oleh M, Sodomo, sekolah merupakan lembaga yang menghendaki kehadiran penuh kelompok-kelompok umur tertentu dalam ruang kelas yang dipimpin oleh seorang pendidik untuk mempelajari kurikulum yang berkelanjutan. ${ }^{26}$ Hadari Nawawi berpendapat bahwa sekolah merupakan lembaga atau saranna bersosialisasi sekelompok orang untuk

${ }^{24}$ Depag RI, Al-Qur"an dan Terjemahnya, (Jakarta: Departemen Agama, 1990), hlm. 561.

${ }^{25}$ Amir Daien Indrakusuma, Pengantar Ilmu Pendidikan, (Surabaya: Usaha Nasional, 1973), 109

${ }^{26}$ M Soedomo, Sekitar Ekesistensi Sekolah, (Yogyakarta: Henedita Offset, 1987), 25 
mencapai suatu tujuan. ${ }^{27}$ Dalam mencapai suatu tujuan yang telah ditentukan seorang guru dan siswa melakukan proses belajar mengajar di sekolah.

Konsep pendidikan sekolah menurut pendidikan Islam adalah lembaga pendidikan formal yang efektif menghantarkan anak pada tujuan yang ditetapkan. Sekolah yang dimaksud adalah membimbing, mengarahkan, dan mendidik sehingga lembaga tersebut menghendaki kehadiran kelompok-kelompok umur tertentu dalam ruang kelas yang dipimpin oleh guru untuk mempelajari kurikulum bertingkat. $^{28}$

Sebagai pusat pendidikan formal, lahir dan berkembang dari pemikiran efisiensi dan efektivitas di dalam pemberian pendidikan kepada masyarakat. Sekolah sebagai perangkat masyarakat yang bertugas memberikan pendidikan. Perangkat diatas dikelola secara formal, mengikuti haluan yang pasti. Haluan tersebut tercermin di dalam falsafah dan tujuan, penjenjangan, kurikulum pengadiministrasian serta pengelolaannya. ${ }^{29}$

Sekolah melakukan pembinaan pendidikan untuk peserta didiknya didasarkan atas kepercayaan dan tuntutan lingkungan keluarga dan masyarakat yang tidak mampu untuk mengembangkan pendidikan di lingkungan masing-masing. Hal tersebut dilakukan karena mengingat berbagai keterbatasan yang dipunyai oleh orang tua. Namun tanggung jawab utama pendidikan tetap berada pada tangan orang tua yang bersangkutan. Sekolah hanyalah meneruskan dan mengembangkan pendidikan yang telah diletakkan dasar-dasarnya oleh lingkungan keluarga sebagai lingkungan pendidikan informal.

Sekolah sebagai tempat untuk mensosialisasikan nilai-nilai yang hidup dalam masyarakat. Sehingga sekolah menjadi jembatan penghubunga antara lingkungan keluarga menuju masyarakat. ${ }^{30}$ Pendidikan di sekolah merupakan lanjutan dari pendidikan keluarga. Sekolah berfungsi sebagai pembantu keluarga dalam memberikan pendidikan dan pengajaran kepada anak didik, sekolah merupakan lanjutan dari apa yang diberikan oleh keluarga. Disamping itu, kehidupan di sekolah

\footnotetext{
${ }^{27}$ Hadari Nawawi, Organisasi Sekolah dan Pengelolaan Kelas Sebagai Lembaga Pendidikan, Jakarta Gunung Agung, 1985), 25

28 Abu Ahmadi, Sosiologi Pendidikan, Cetakan ke-2, (Jakarta: Rineka Cipta, 2004), 108

29 Tim Dosen FIP-IKIP Malang, Pengantar Dasar-Dasar Kependidikan, Cetakan ke 4, (Surabaya: Usaha Nasional, 2006), 146

${ }^{30}$ Damsar, Pengantar Sosiologi Pendidikan, Cetakan ke 2, Jakarta: Kencana Prenada Media Group, 2012), 74
} 
adalah jembatan bagi anak yang menghubungkan kehidupan dalam keluarga dan kehidupan dalam masyarakat.

\section{c. Masyarakat}

Masyarakat merupakan kelompok terbesar dari manusia dimana pada manusia tersebut terjaring suatu kebudayaan yang dirasakan sebagai suatu kebudayaan. Dari segi konsep pendidikan masyarakat adalah populasi yang mempunyai beraneka ragam kebudayaan. ${ }^{31}$ Dalam dunia pendidikan masyarakat dikatakan lingkungan pendidikan yang non formal. Oleh karena itu, masyarakat memberikan pendidikan secara sengaja dan berencana kepada seluruh anggotanya tetapi tidak sistematis. Secara fungsional masyarakat menerima anggotanya yang bermacam-macam dan mengarahkan menjadi anggota yang baik untuk tercapainya kesejahteraan masyarakat.

Menurut pendidikan Islam, konsep pendidikan masyarakat sebagai salah satu alternatif untuk meningkatkan mutu sumber daya manusia dan kebudayaan dalam melawan kebodohan bangsa. Hal tersebut dilaksanakan melalui berbagai kegiatan masyarakat, sehingga masyarakat mampu berinovasi sesuai dengan perkembangan zaman dan mempunyai tanggungjawab yang penuh dalam kesejahteraan bangsa. Kualitas tersebut baik dibidang ilmu, ketrampilan, maupun kebijaksanaan atau dengan kata lain meningkatkan wawasan kognitif, afektif dan psikomotorik. ${ }^{32}$

Menurut Hamka, peserta didik dapat dikatakan sebagai wujud dari bentuk akhlak masyarakat dimana ia berada. Hal ini karena kehidupan setiap anggota masyarakat dalam sebuah komunitas sosial, merupakan miniatur kebudayaan yang akan dilihat dan dicontoh oleh setiap peserta didik. ${ }^{33}$ Eksistensi masyarakat merupakan laboratorium dan sumber makro yang penuh alternatif untuk memperkaya proses pendidikan. Setiap anggota memiliki peranan dan tanggung jawab moral terhadap terlaksananya proses pendidikan yang efektif. Kesemua unsur yang ada hendaknya senantiasa bekerjasama secara timbal balik sebagai alat sosialkontrol bagi pendidikan. ${ }^{34}$

\footnotetext{
${ }^{31}$ Fuad Ihsan, Dasar-Dasar Kependidikan, Cetakan ke-1, (Jakarta: Rineka Cipta, 1991), 84

${ }^{32}$ Kuntowijoyo m, Paradigma Islam: Interpretasi untuk. Aksi, (Bandung: Mizan, 1991), 228-230

${ }_{33}$ M. Suyudi, Filsafat Pendidikan Islam Kajian Filosofis dan Pemikiran Pendidikan Islam, (Yogyakarta: Belukar, 2014), 286

34 Ramayulis, Ensiklopedi Tokoh Pendidikan Islam, Cetakan ke 1, Jakarta: Quantum Teaching, 2005), 275
} 
Masyarakat muslim merupakan masyarakat yang padu. Sehingga, pendidikan dilaksanakan melalui kerjasama yang utuh. ${ }^{35}$ Dalam Islam, tanggung jawab masyarakat terhadap pendidikan bersifat individual maupun kelompok. Pembinaan lingkungan masyarakat dengan pendidikan islam selain TPQ dapat dilakukan dengan cara mengadakan berbagai kegiatan yang bersifat menumbuh kembangkan pemahaman tentang Islam. Kegiatan tersebut meliputi pengajian, silaturahmi, gotong royong, dan dialog interaktif yang bertema tentang pendidikan Islam.

\section{Integrasi Tri Pusat Pendidikan dalam Pendidikan Agama Islam}

Lingkungan pendidikan yang mempunyai pengaruh besar terhadap perkembangan anak meliputi keluarga, sekolah dan masyarakat. ${ }^{36}$ Untuk mewujudkan pendidikan yang berkualitas, maka ketiga lingkungan pendidikan (keluarga, sekolah dan masyarakat) harus bekerja sama secara sehat dan harmonis. Sebab antara pendidikan dengan peradaban yang dihasilkan suatu masyarakat memiliki korelasi positif, semakin berpendidikan suatu masyarakat maka semakin tinggi pula peradaban yang dihasilkan demikian juga sebaliknya.

Orang tua, sekolah dan masyarakat memiliki tanggung jawab yang sama. Maka secara tidak langsung telah mengadakan kerja sama yang erat dalam praktik pendidikan. Kerjasama yang erat itu tampak ketika anak meletakkan dasar-dasar pendidikan, terutama dalam pembentukan kepribadian. Kemudian dikembangkan dalam lingkungan sekolah dengan materi pendidikan berupa ilmu dan ketrampilan. Tidak kalah juga masyarakat ikut berperan serta mengontrol, menyalurkan serta membina dan meningkatkannya. Karena masyarakat merupakan lingkungan pemakai (the user) dari prodek pendidikan yang diberikan oleh keluarga dan sekolah. ${ }^{37}$

Perlu disadari bahwa ketiga lingkungan pendidikan tersebut mempunyai tanggungjawab dan pembinaan yang penuh. Secara tidak langsung lingkungan tersebut melakukan kerjasama yang harmonis. ${ }^{38}$ Kerjasama tersebut adalah orang tua meletakkan dasar kependidikan kepada anak melalui keluarga, terutama dalam membentuk kepribadian anak. Kemudian dikembangkan melalui materi berupa ilmu dan ketrampilan di sekolah. Dan akhirnya orang tua menilai dan mangawasi hasil dari pendidikan di

\footnotetext{
${ }^{35}$ Moh. Haitami Salim, Studi Ilmu Pendidikan Islam, (Yogyakarta: Ar-Ruzz Media, 2012), 270

${ }^{36}$ Hasan Basri, Ilmu Pendidikan Islam, (Bandung: Pustaka Setia, 2010), 261

${ }^{37}$ Ihsan, Dasar-Dasar,,, 91

${ }^{38}$ Fuad Ihsan, Dasar-Dasar Kependidikan, (Jakarta: PT Rineka Cipta, 2008), 90
} 
sekolah melalui masyarakat. Karena masyarakat andil dalam mengontrol dan membina pendidikan anak.

Hubungan timbal balik antara keluarga, sekolah dan masyarakat dalam menyalurkan pendidikan untuk mengembangkan kepribadian anak. Ketiga lingkungan tersebut mempunyai tujuan bersama yaitu membentuk anak menjadi anggota masyarakat yang baik untuk bangsa, negara dan agama. Keluarga sebagai dasar pendidikan, sekolah sebagai pengembang pendidikan dan masyarakat sebagai pemakai. Bila masing-masing lingkungan mampu berbuat yang sama, maka tujuan nasional akan tercapai. Kerjasama yang terpadu tersebut sangat menguntungkan dalam perkembangan dan pertumbuhan anak, baik secara jasmani maupun rohani, mental spiritual dan fisikal.

Pendidikan merupakan bagian dari kewajiban yang mesti dijalankan oleh manusia, hal ini dikarenakan pendidikan adalah kunci penyadaran manusia menjadi hamba yang sesungguhnya. Poin penting pendidikan Islam, adalah bahwa diantara aspek-aspek pokok dalam pendidikan anak yang disebutkan di atas, mulai dari pendidikan ibadah, pendidikan akhlak, pendidikan al-Qur'an, pendidikan puasa dan haji, serta pendidikan fiqih harus berdampak pada penanaman akidah pada anak. ${ }^{39}$ Marimba (1986) menggambarkan bahwa pendidikan Islam sebagai bimbingan pribadi muslim, adalah bimbingan jasmani dan rohani berdasarkan hukum-hukum agama islam menuju kepada terbentuknya kepribadian utama menurut ukuran-ukuran Islam. ${ }^{40}$

Berdasar uraian diatas maka dapat disimpulkan bahwa bidang materi dan metode pendidikan Islam dapat dipisahkan, tetapi dalam praktiknya satu sama lain tidak dapat dipisahkan. Setiap kegiatan pendidikan selalu mencakup kawasan kognitif, afektif dan psiko-motorik. Hal ini karena adanya potensi-potensi yang dimiliki oleh manusia saling berkaitan dan merupakan satu kesatuan. Sumber pendidikan Islam terdiri dari: (1) Sumber Ilahi yaitu sumber yang berasal langsung dari tuhan, yang meliputi Al-Qur"an, Hadis, dan Alam Semesta sebagai ayat kauniyah yang perlu ditafsirkan; (2) Sumber Insaniyah adalah sumber yang berasal dari usaha-usaha yang dilakukan oleh manusia, yang berupa Ijtihad manusia dari fenomena yang muncul dan dari kajian lebih lanjut dari sumber Ilahi yang masih bersifat global. ${ }^{41}$

${ }^{39}$ M. Quraish Shihab, Tafsir al-Misbah, Volume. 7, (Jakarta: Lentera Hati, 2010 ), 351

40 Ahmad D. Marimba, Pengantar Filsafat Pendidikan Islam, ( Bandung: Al-Ma"arif, 1986), 23, sebagai perbandingan lihat Syekh Mustofa al-Ghulayaini, I'dhat al-Nasyiin, (Beirut, al-Thiba"at wa al-Natsir, 1953), 185.

41 Abdul Fatah Jalal, Asas-Asas Pendidikan Islam, ( Bandung: Diponegoro, 1988), 143. Hasan Langgulung, menambahkan bahwa sumber pendidikan Islam ada 6 ( enam ), yaitu: (1) Al-Qur'ân; (2) Hadis; (3) Atsar Sahabat; (4) Kemaslahatan Sosial; (5) Nilai-nilai dan kebiasaan sosial; (6) Pemikir-pemikir 
Pendidikan agama Islam sebagai proses bimbingan dan asuhan terhadap anak didik yang tujuan akhirnya perserta didik mampu memahami apa yang terkandung di dalam Islam secara keseluruhan, menghayati makna dan maksud serta tujuannya dan pada akhirnya dapat mengaplikasikan dalam kehidupan sehari-hari. Selain itu, untuk pedoman hidup dalam mengarungi berbagai dinamika kehidupan, sehingga dapat mendatangkan keselamatan dunia dan akhirat. ${ }^{42}$

Pendidikan agama Islam merupakan usaha sadar untuk menyiapkan peserta didik dalam meyakini, memahami, menghayati dan mengamalkan agama Islam melalui kegiatan bimbingan, pengajaran, dan latihan dengan memperhatikan tuntutan untuk menumbuhkan sikap toleransi dengan agama yang lain dalam hubungan yang harmonis antar umat beragama dalam masyarakat untuk mewujudkan persatuan nasional. ${ }^{43}$ Pendidikan agama Islam tidak hanya bersifat teoritis saja, namun juga bersifat praktis. Ajaran agama Islam tidak memisahkan antara kepercayaan dan perbuatan.

Pendidikan agama Islam merupakan usaha sadar dan terencana untuk menyiapkan siswa dalam meyakini, memahami, dan mengamalkan Islam melalui kegiatan bimbingan, pengajaran dan latihan. Pendidikan agama Islam pada hakekatnya merupakan sebuah proses itu, dalam perkembangannya juga dimaksud sebagai rumpun mata pelajaran yang diajarkan di sekolah maupun perguruan tinggi. ${ }^{44}$ Pendidikan agama Islam dapat dimaknai dari dua sisi yaitu: sebagai sebuah mata pelajaran seperti dalam kurikulum sekolah umum dan sebagai rumpun pelajaran yang terdiri atas mata pelajaran Aqidah Akhlak, Fiqih, AlQur'an-Hadis, Sejarah Kebudayaan Islam dan Bahasa Arab seperti yang diajarkan di Madrasah. ${ }^{45}$

Sesuai dengan perkembangan masyarakat yang semakin dinamis sebagai konsekuensi dari kemajuan ilmu pengetahuan dan teknologi, maka aktualisasi dari nilainilai Al-Qur'an menjadi sangat penting. Karena tanpa aktualisasi kitab suci ini umat Islam akan menghadapi kendala dalam upaya internalisasi nilai-nilai Qur'ani sebagai upaya pembentukan pribadi umat Islam yang bertaqwa, berakhlak mulia, cerdas, maju dan mandiri atau denga kata lain insan kamil. Pribadi yang semacam ini yang menjadi

Islam, lihat Hasan Langgulung, Beberapa Pemikiran tentang Pendidikan Islam, ( Jakarta: Pustaka Al-Husna, $1986), 32$

42 Zakiyah Darajat, Ilmu Pendidikan Islam, Jakarta: Bumi Aksara, 2007), 88

43 Muhaimin, et.al. Paradigma Pendidikan Islam Upaya Mengefektifkan Pendidikan Agama Islam di Sekolah, (Bandung: PT Remaja Rosdakarya, 2002), 75

${ }^{44}$ Nazarudin, Manajemen Pembelajaran, (Yogyakarta: Teras, 2007), 12.

${ }^{45}$ Rohmat Mulyana, Mengartikulasikan Pendidikan Nilai, (Bandung: Alfabeta, 2004),198. 
tujuan dari pendidikan agama Islam. Pendidikan agama Islam ditujukan sebagai proses transfer pengetahuan (transfer of knowledge), transfer metode (transfer of methodology) dan transfer nilai-nilai (transfer of values). ${ }^{46}$

Secara normatif tujuan yang ingin dicapai oleh pendidikan agama Islam meliputi tiga dimensi: Pertama, dimensi spiritual, yaitu iman, taqwa dan akhlak mulia (yang tercermin dalam ibadah dan mu'amalah). Kedua, dimensi budaya, yaitu kepribadian yang mantap dan mandiri, tanggungjawab kemasyarakatan dan kebangsaan. Dimensi ini secara universal menitikberatkan pada pembentukan kepribadian muslim sebagai individu yang diarahkan kepada peningkatan dan pengembangan faktor dasar (bawaan) dan faktor ajar (lingkungan) dengan berpedoman kepada nilai-nilai keislaman. Ketiga, dimensi kecerdasan yang membawa kemajuan, yaitu, serdas, kreatif, disiplin, inovatif, produktif dan sebagainya. ${ }^{47}$

Untuk mewujudkan pendidikan yang berkualitas, ketiga lingkungan pendidikan yang erat dalam proses pembelajaran PAI. Melalui orang tua nilai-nilai ajaran agama Islam diajarkan sejak kecil. Orang tua mengajarkan kepada anakny untuk taat beribadah kepada Allah seperti shalat, puasa, membaca Al-Qur'an dan lain-lain. Di sekolah juga diajarkan tentang ibadah dan lainnya. Melalui kegiatan di masyarakat seperti TPA juga diajarkan tentang nilai-nilai ajaran Islam.

\section{Catatan Akhir}

Tri pusat pendidikan adalah tiga pusat pendidikan yang meliputi keluarga, sekolah dan masyarakat. Ketiga lingkungan tersebut mempunyai tugas dan tanggung jawab dalam mencerdaskan anak bangsa. Keluarga, sekolah dan masyarakat sebagai penanggungjawab pendidikan yang harus selalu bekerjasama secara harmonis. Dari ketiga lingkuang pendidikan tersebut akan hancur tidak berjalan satu arah jika tidak bersatu padu.

Ketiga lingkungan pendidikan sebagai tempat menanamkan nilai-nilai ajaran agama Islam yang mempunyai tujuan untuk membentuk anak menjadi pribadi yang baik secara jasmani maupun rohani. Keluarga sebagai penanaman pertama kali tentang ajaran agama Islam, sekolah sebagai sarana untuk mengembangkan dan masyarakat sebagai sarana untuk mengaplikasikannya.

21

46 Ahmad Tamtowi, Pendidikan Islam diera transformasi Global, (Semarang: PT Pustaka Rizki Putra),

${ }^{47}$ Ibid, 22-24 
Pendidikan agama Islam merupakan salah satu bekal baik kehidupan dunia maupun akherat. Sehingga pelaksaan proses pendidikan agama Islam harus dilakukan melalui tri pusat pendidikan. Peran keluarga, sekolah dan masyarakat yang kompak akan mempunyai pengaruh yang kuat dalam menciptakan sumber daya manusia yang genius, berkualitas tinggi dan berkepribadian yang luhur.

\section{Daftar Rujukan}

'Abd Muhammad al-'Aliy, the Family Structure in Islam (Maryland: International Gfaric Printing Service, t.th). M. Quraish Shihab. 1997. Membumikan al-Qur'an. Cetakan XV. Bandung: Mizan.

Ahmadi, Abu. 2004. Sosiologi Pendidikan. Cetakan ke-2. Jakarta: Rineka Cipta.

Ahmadi Abu dan Nur Uhbiyati. 1991. Ilmu Pendidikan, Cetakan ke-3. Jakarta: Rineka Cipta.

-----..- 2007. Ilmu Pendidikan. Cetakan ke 2. Jakarta: PT. Rineka Cipta.

Asrohah, Hanun dan Anas Alamsyah. 2012. Buku Ajar Pengembangan Kurikulum. Cetakan ke-4. Surabaya: Kopertais IV Press.

Basri, Hasan. 2010. Ilmu Pendidikan Islam. Bandung: Pustaka Setia.

Budiyanto, Mangun. 2010. Ilmu Pendidikan Islam. Yogyakarta: Griya Santri.

Chaer, Moh. Toriqul. "Peran Madrasah Dalam Menghadapi Era Globalisasi Dan

Budaya." Muaddib: Studi Kependidikan dan Keislaman 6, no. 2 (2 Januari 2017): 182. https://doi.org/10.24269/muaddib.v6n2.2016.182-201.

Chaer, Moh Toriqul. "Self-Efficacy Dan Pendidikan" 3 (2016): 17.

Daien, Amir Indrakusuma. 1973. Pengantar Ilmu Pendidikan. Surabaya: Usaha Nasional.

Damsar. 2012. Pengantar Sosiologi Pendidikan. Cetakan ke 2. Jakarta: Kencana Prenada

Media Group.

Darajat, Zakiyah. 2007. Ilmu Pendidikan Islam. Jakarta: Bumi Aksara.

Haitami, Moh. Salim. 2012. Studi Ilmu Pendidikan Islam. Yogyakarta: Ar-Ruzz Media.

Ihsan, Fuad. 1997. Dasar-Dasar Kependidikan. Jakarta: PT Rineka Cipta 2008. Dasar-Dasar Kependidikan. Jakarta: PT Rineka Cipta.

Koesoema, Doni A. 2007. Pendidikan Karakter: Strategi Mendidik Anak di Zaman Global. Jakarta: Grasindo.

Kuntowijoyo. 1991. Paradigma Islam: Interpretasi untuk Aksi. Bandung: Mizan.

Langgulung, Hasan. 1995. Manusia dan Pendidikan: Suatu Analisa Psikologis dan Pendidikan. Cetakan ke-3. Jakarta: Al-Husna Zikra

Muhaimin, et.al. 2002. Paradigma Pendidikan Islam Upaya Mengefektifkan Pendidikan Agama Islam di Sekolah. Bandung: PT Remaja Rosdakarya.

Inkeles. 1966."The Modernization of Man," dalam Weimer (ed) . Modernization : The Dynamics of Growth. Voice of Amerika Forum Lectures

Joesoef, Daoed.2001. "Pembaharuan Pendidikan dan Pikiran", dalam Sularto (ed). Masyarakat Warga dan Pergulatan Demokrasi: Antara Cita dan Fakta. Jakarta: Kompas

Mulyana, Rohmat. 2004. Mengartikulasikan Pendidikan Nilai. Bandung: Alfabeta.

Nawawi, Hadari. 1985. Organisasi Sekolah dan Pengelolaan Kelas Sebagai Lembaga Pendidikan. Jakarta Gunung Agung.

Nazarudin. 2007. Manajemen Pembelajaran. Yogyakarta: Teras. 
Pamungkas, Imam. 2012. Akhlak Muslim Modern: Membangun Generasi Muda. Bandung: Marja.

Ramayulis. 2005. Ensiklopedi Tokoh Pendidikan Islam. Cetakan ke 1. Jakarta: Quantum Teaching

Soedomo, M, 1987. Sekitar Eksistensi Sekolah. Yogyakarta: Henedita Offset

Suyudi, M. 2014. Filsafat Pendidikan Islam dalam Kajian Filososfis dan Pemikiran Pendidikan Islam. Yogyakarta: Belukar.

Suyudi. 2005.Pendidikan dalam Perspektif Al-Qur'an. Yogyakarta: Penerbit Mikraj 2014. Rancang Bangun Pendidikan Islam. Yogyakarta: Belukar.

Tamtowi, Ahmad. Pendidikan Islam diera transformasi Global. Semarang: PT Pustaka Rizki Putra

Tim Dosen FIP-IKIP Malang. 2006. Pengantar Dasar-Dasar Kependidikan. Cetakan ke 4. Surabaya: Usaha Nasional.

Uhbiyati, Nur. 1998. Ilmu Pendidikan Islam. Cetakan ke-2. Bandung: CV. Pustaka Setia. Zuhairini, et.al. 1995. Filsafat Pendidikan Islam. Cetakan ke-2. Jakarta: Bumi Aksara. 